Jurnal Riset Manajemen Sains Indonesia (JRMSI) | Vol 12, No. 2, 2021 e-ISSN: 2301-8313

http://doi.org/10.21009/JRMSI

DOI: doi.org/10.21009/JRMSI.012.2.07

\title{
MODEL PERILAKU KEPUTUSAN PEMBELIAN PRODUK BERBASIS AGEN: FENOMENA PENGARUH MEDIA SOSIAL
}

\author{
Ambara Purusottama \\ Universitas Prasetiya Mulya \\ Email: ambara.purusottama@pmbs.ac.id
}

\begin{abstract}
ABSTRAK
Influencer media sosial dalam pemasaran digital telah menjadi fenomena baru karena mereka dapat menggantikan peran influencer tradisional. Namun, diskusi tentang fenomena ini masih kurang jelas dalam literatur akademis sejauh pengetahuan kita. Penelitian ini bertujuan untuk memahami peran social media influencer dalam interaksi sosial dan implikasinya terhadap keputusan pembelian produk kecantikan untuk memberikan gambaran suatu perusahaan dalam mengambil keputusan bisnis menggunakan Instagram. Simulasi pemodelan berbasis agen (ABM) digunakan untuk memahami fenomena ini. Simulasi tersebut merupakan kombinasi dari pendekatan deduksi yang memanfaatkan teori perilaku terencana (TPB) dan pendekatan induksi melalui observasi kehidupan nyata. Beberapa parameter digunakan untuk mendukung proses simulasi, antara lain jumlah pengikut, jumlah suka/komentar, jumlah posting, dan daya tarik influencer. Berakhir dengan memutuskan untuk membeli suatu produk atau tidak, yang diidentikkan dengan angka penjualan. Penelitian ini mengklasifikasikan tiga influencer yang berbeda dengan karakteristik yang telah ditentukan. Simulasi menunjukkan bahwa penjualan produk menggunakan Influencer [B] menghasilkan penjualan tertinggi melalui iterasi berulang, diikuti oleh Influencer [A] dan Influencer [C]. Beberapa parameter juga menjelaskan fenomena social media influencer dalam keputusan pembelian produk. Studi ini menemukan bahwa jumlah konten yang diposting merupakan parameter paling signifikan dalam keputusan pembelian produk. Namun, parameter lain juga memberikan kontribusi yang signifikan. Melalui kombinasi yang tepat, organisasi dapat mempertimbangkan parameter ini mengenai kontribusi influencer media sosial terhadap penjualan produk mereka. Keterbatasan penelitian dan rekomendasi disajikan secara lengkap dalam artikel ini.
\end{abstract}

Kata Kunci: pemodelan berbasis agen, Instagram, keputusan pembelian produk, influencer media sosial, interaksi sosial. 
Jurnal Riset Manajemen Sains Indonesia (JRMSI) | Vol 12, No. 2, 2021 e-ISSN: 2301-8313 http://doi.org/10.21009/JRMSI

\section{PENDAHULUAN}

Media sosial merupakan fenomena yang menarik perhatian dalam kajian konsep pemasaran. Aplikasi media sosial yang ditransformasi bukan lagi sekadar platform komunikasi. Saat ini, ia berubah menjadi platform kolaborasi untuk meningkatkan kinerja produk dan layanan. Instagram merupakan platform media sosial yang dapat mengirimkan pesan secara cepat dan instan kepada publik. Miles (2013) menekankan pentingnya peran Instagram dalam membantu memasarkan produk dan layanan. Hal ini menunjukkan bahwa sebanyak $50 \%$ brand ternama menggunakan Instagram sebagai instrumen pemasaran. Sebanyak lima juta gambar diunggah di Instagram setiap hari. Seiring waktu, media sosial menjadi semakin populer dan telah membuat organisasi meninggalkan pemasaran tradisional.

Pemasaran media sosial memiliki kemampuan yang lebih spesifik daripada pemasaran tradisional (Tuten, 2008). Platform pemasaran media sosial dapat disesuaikan sesuai dengan segmentasi pasar sasaran sehingga pesan yang disampaikan dapat lebih efektif. Pemasaran media sosial juga memiliki keuntungan dari perspektif efisiensi biaya dan waktu. Pemasaran media sosial terbukti lebih efisien dalam menggunakan biaya karena dapat menjangkau pasar yang lebih luas dibandingkan pemasaran tradisional. Selain itu, penyebaran informasi melalui media sosial jauh lebih cepat. Berkat teknologi, penyebaran informasi menjadi lebih efisien. Pesatnya perkembangan media sosial membuat para aplikator mengubah model bisnis mereka, tidak lagi menyediakan platform untuk komunikasi biasa dan menyediakan platform untuk memasarkan produk mereka.

Influencer media sosial telah berhasil memposisikan diri sebagai tokoh penting dalam perkembangan pemasaran modern. Jin dkk. (2019) menemukan bahwa orang lebih memilih influencer media sosial karena persepsi sosial mereka daripada selebriti pemasaran tradisional. Melalui aktivitas media sosial mereka, influencer online dapat mempengaruhi sikap, tindakan, dan perilaku pengikut mereka dalam mekanisme yang dikenal sebagai pemasaran influencer (Watts \& Dodds, 2014). Influencer media sosial dapat memecahkan masalah yang dihadapi oleh organisasi. Beberapa masalah signifikan yang dihadapi merek adalah mengenali dan memilih apa yang disebut influencer yang dapat secara signifikan memengaruhi keputusan pembelian.

Keputusan pembelian merupakan respon pelanggan terhadap penyebaran informasi dari sumber manapun. Pelanggan akan membeli suatu produk jika merasa produk tersebut dapat menyelesaikan masalah yang dihadapi. Dalam lingkup perilaku pelanggan, salah satu teori 
Jurnal Riset Manajemen Sains Indonesia (JRMSI) | Vol 12, No. 2, 2021 e-ISSN: 2301-8313 http://doi.org/10.21009/JRMSI

terkenal yang dapat menjelaskan keputusan pembelian adalah teori perilaku terencana (TPB), sebuah teori berbasis psikologis yang menjelaskan perilaku individu dan dipengaruhi oleh tiga faktor utama: sikap, norma subjektif. , dan kontrol perilaku yang dirasakan. Teori ini dapat diterapkan dalam berbagai disiplin ilmu, termasuk pemasaran dan perilaku konsumen. Dalam belanja online, teori ini juga dapat memberikan nilai tambah dalam menjelaskan perilaku pembelian (Pan \& Truong, 2018).

Penelitian sebelumnya telah menjelaskan pentingnya mempelajari perilaku konsumen dalam mengambil keputusan pembelian. Meskipun disajikan dalam konteks yang berbeda, teori ini telah terbukti memiliki keterikatan yang kuat terhadap keputusan pembelian. Studi TPB tentang topik pemasaran menggunakan lebih banyak metodologi survei untuk memahami konteks ini melalui tinjauan pustaka yang sistematis. Implikasinya, instrumen statistik berupa model regresi merupakan pendekatan yang paling banyak digunakan. Sementara itu, banyak metode yang dapat menjelaskan konsep ini. Oleh karena itu, posisi penelitian ini menggunakan pendekatan simulasi dan studi kasus produk kecantikan sebagai strategi penelitian untuk menjelaskan fenomena influencer media sosial.

Penelitian ini bertujuan untuk memahami perilaku pembelian tingkat mikro melalui model konseptual fenomena influencer media sosial menggunakan pemodelan berbasis agen. Selanjutnya, penelitian ini mencoba membantu pengambilan keputusan organisasi dengan memodelkan interaksi sosial dan pemahaman intuitif tentang perubahan fenomena influencer media sosial. Oleh karena itu, pertanyaan penelitian berikut dapat dirumuskan:

RQ1: Apa struktur mikro atau model konseptual perilaku pembelian dalam konteks influencer media sosial?

RQ2: Apa logika interaksi untuk melakukan perilaku pembelian influencer media sosial?

RQ3: Bagaimana fenomena influencer media sosial mempengaruhi perilaku pembelian konsumen?

Studi ini berkontribusi pada literatur keputusan pembelian produk melalui fenomena rekonstruksi ke dalam model komputasi. Struktur penulisan diawali dengan pendahuluan yang membahas tentang fenomena yang ada, gap penelitian, tujuan penelitian, tinjauan pustaka, dan pengembangan hipotesis. Kemudian dilanjutkan dengan metode penelitian, yang menguraikan bagaimana penelitian akan dilakukan untuk memenuhi tujuan penelitian. Analisis dan diskusi mengikuti struktur masing-masing, yang membahas temuan penelitian dan penjelasan lebih lanjut. Terakhir, penelitian ditutup dengan kesimpulan dan saran. 
Jurnal Riset Manajemen Sains Indonesia (JRMSI) | Vol 12, No. 2, 2021 e-ISSN: 2301-8313 http://doi.org/10.21009/JRMSI

\section{TELAAH PUSTAKA DAN PENGEMBANGAN HIPOTESIS}

\section{Pemasaran media social}

Pesatnya perkembangan teknologi internet menawarkan ketersediaan jaringan, jangkauan yang mudah, dan penerimaan masyarakat yang berbasis social media marketing. Teknologi internet yang pada awal perkembangannya mulai goyah, mulai terbentuk ketika beberapa organisasi menggunakan teknologi tersebut untuk mendukung bisnis mereka. Saat ini, Internet merupakan teknologi fundamental bagi pengembangan bisnis berbasis digital. Beberapa organisasi telah berhasil berinovasi melalui teknologi internet (Gomber et al., 2018). Facebook, Instagram, Twitter, dan YouTube mungkin adalah organisasi paling sukses yang menggunakan teknologi Internet untuk meningkatkan bisnis mereka. Melalui produk mereka, konsep pemasaran media sosial berkembang secara signifikan.

Popularitas pemasaran media sosial menarik bisnis untuk menggunakan metode ini untuk menarik lebih banyak pelanggan untuk membeli produk mereka selain melalui pemasaran tradisional. Organisasi bisnis menggunakan influencer media sosial sebagai "agen" penjualan online mereka untuk menyebarkan informasi tentang produk mereka. Influencer media sosial disebut sebagai individu yang telah membentuk jaringan pengikut sosial yang signifikan dan dianggap sebagai pembuat selera yang sah di satu atau lebih segmen pasar (De Veirman et al., 2017). Influencer ini bisa berupa selebriti konvensional atau individu yang menjadi terkenal melalui kehadiran mereka di media sosial.

Influencer media sosial adalah instrumen organisasi yang digunakan untuk meningkatkan penyampaian nilai kepada pelanggannya. Tokoh social influencer harus memiliki atribut yang dapat menarik individu untuk menggunakan produk atau jasa yang dipromosikannya. Beberapa parameter telah ditetapkan sebagai indikator untuk memilih tokoh media influencer dalam suatu aplikasi, seperti jumlah pengikut, jumlah suka, jumlah komentar atau ulasan, dll. Parameter ini merupakan indikator yang menentukan apakah seseorang akan menjadi seorang influencer. Sosok influencer akan mewakili suatu produk dan mempengaruhi konsumen dalam keputusan pembelian produk.

Konsep influencer merupakan instrumen untuk membantu mengkomunikasikan produk melalui ikatan emosional (Jin et al., 2019). Singkatnya, influencer media sosial memainkan peran penting dalam membuat keputusan pembelian karena mereka dapat memiliki efek yang lebih substansial melalui angka-angka tertentu. Menggunakan model AIDA, Jinyevu et al. (2018) menjelaskan pentingnya karakter influencer dalam merangsang pembelian suatu 
Jurnal Riset Manajemen Sains Indonesia (JRMSI) | Vol 12, No. 2, 2021 e-ISSN: 2301-8313 http://doi.org/10.21009/JRMSI

produk. Influencer media sosial memberikan daya tarik yang lebih tinggi daripada influencer tradisional.

\section{Influencer Media Sosial, TPB, dan Keputusan Pembelian}

TPB adalah model perilaku yang digunakan oleh penelitian lain untuk memahami perilaku individu dan organisasi, termasuk perilaku pembelian atau pembelian (Giampietri et al., 2018; Merminod et al., 2019). Perilaku manusia didorong oleh beberapa faktor utama, misalnya sikap, norma subjektif, dan kontrol perilaku. Perilaku adalah manifestasi yang cukup kompleks pada manusia; mempelajari perilaku manusia mungkin menjadi tantangan terbesar bagi para peneliti. Dengan demikian, pergeseran dari tindakan ke niat menjadi relevan karena masih dalam skor yang sama dan juga lebih mudah untuk diprediksi (Miralles et al., 2017). Teori perilaku terencana telah digunakan sebagai kerangka untuk mempelajari berbagai bentuk perilaku manusia (Ajzen \& Sheikh, 2013), salah satunya adalah perilaku pembelian. Kehebatan teori ini adalah dapat menjelaskan perilaku pembelian atau keputusan pembelian. Penerapan teori ini pada pembelian juga dapat diterapkan secara kontekstual (Awaluddin \& Hamid, 2019; Piroth et al., 2020).

Sikap merupakan faktor internal yang mempengaruhi perilaku individu terhadap suatu produk yang didukung oleh influencer tertentu. Jika individu merasa bahwa iklan produk melalui influencer media sosial memiliki nilai positif dan dapat memberikan manfaat, mereka akan merespons secara positif. Sikap biasanya didorong oleh pengetahuan dan pengalaman masa lalu. Kedua, norma subjektif menjadi dasar penilaian individu yang dipengaruhi oleh interaksi sosialnya terhadap keputusan pembelian produk. Interaksi sosial adalah figur sosial yang mempengaruhi perilaku individu untuk membeli suatu produk tertentu. Jika influencer sosial pada produk tertentu memengaruhi penilaian positif, maka respons positif pasti akan terjadi (Youn \& Jin, 2017). Ketiga, kontrol perilaku yang dirasakan adalah kepercayaan diri individu terhadap keputusan pembelian produk. Jika individu merasa bahwa suatu produk tertentu dapat dibeli, maka individu tersebut akan merespon secara positif.

TPB dan keputusan pembelian telah terbukti berjalan beriringan dan saling menguntungkan. Konsep TPB berkembang pesat melalui serangkaian modifikasi dengan mengaitkannya dengan ide keputusan pembelian (Nuttavuthisit \& Thøgersen, 2017; Pappas, 2017). Oleh karena itu, dari pengertian tersebut dapat dikembangkan beberapa hipotesis:

H1: Beriklan melalui influencer media sosial memberikan kontribusi yang signifikan terhadap kinerja inisiatif pemasaran; 
Jurnal Riset Manajemen Sains Indonesia (JRMSI) | Vol 12, No. 2, 2021 e-ISSN: 2301-8313 http://doi.org/10.21009/JRMSI

H2: Pengambilan keputusan pembelian produk sepenuhnya ditentukan oleh interaksi antara influencer media sosial dan konsumennya; dan

H3: Pemilihan influencer media sosial menentukan organisasi untuk meningkatkan penjualan produknya.

\section{Pemodelan Berbasis Agen}

Keistimewaan agen memunculkan ABM sebagai kekuatan untuk memecahkan masalah heterogen (Macal \& North, 2009). Metode ini berbeda dengan simulasi diskrit lainnya seperti simulasi kejadian diskrit, dinamika sistem, dan model kuantitatif lainnya. Kekuatan ABM adalah dapat memfasilitasi fenomena sosial yang kompleks. Selanjutnya, pendekatan ini memungkinkan pemodelan interaksi sosial. Dengan memahami heterogenitas antar agen, kebijakan yang lebih efektif dapat diusulkan. Namun, kekhususan ABM menuai kritik tajam karena ketidaksempurnaannya dalam merepresentasikan fenomena nyata.

Kapasitas menonjol ABM antara lain dapat merekonstruksi sebuah fenomena dalam model komputasi. Model ini dapat dilihat sebagai bentuk interaksi antar agen, bagaimana agen berinteraksi, dan hasil interaksi tersebut. Juga, model komputasi memungkinkan pengguna untuk mengeksplorasi fenomena ini lebih lanjut dan memanfaatkannya untuk membantu dalam pengambilan keputusan. Model memungkinkan rekayasa struktural dan intervensi variabel untuk menentukan kinerja perubahan ini dan, tentu saja, untuk memberikan gambaran pengambilan keputusan. Terlepas dari keterbatasannya, ABM dapat menjadi alternatif untuk memahami fenomena yang kompleks. Influencer media sosial adalah peristiwa yang melibatkan interaksi sosial untuk menyebarkan temuan baru (Garcia \& Jager, 2011).

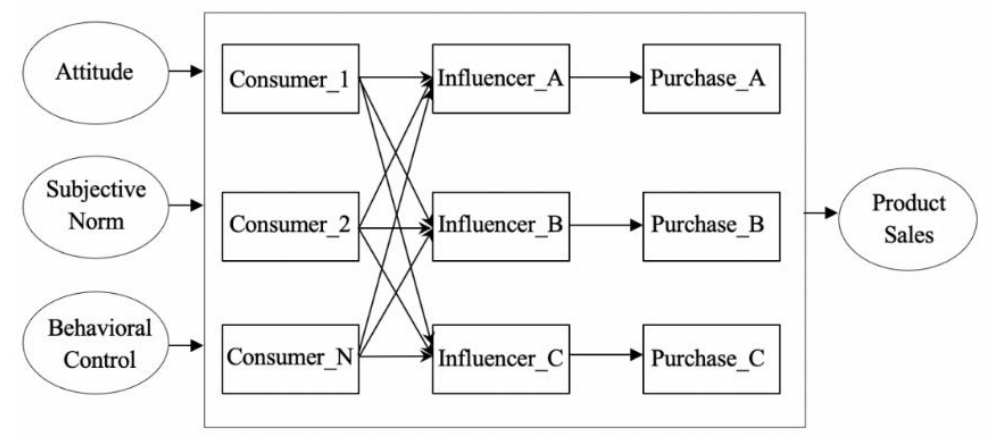

Gambar 1. Kerangka Interaksi Keputusan Pembelian 
Jurnal Riset Manajemen Sains Indonesia (JRMSI) | Vol 12, No. 2, 2021 e-ISSN: 2301-8313 http://doi.org/10.21009/JRMSI

\section{METODE PENELITIAN}

Penelitian ini menggunakan pendekatan studi kasus, yaitu suatu cara untuk memahami suatu fenomena tertentu (Yin, 2014). Fenomena social media influencer dalam konsep pemasaran berkembang seiring dengan adanya internet dan aplikasi media sosial. Beberapa referensi mencatat bahwa social media marketing dan influencer merupakan saluran yang paling efektif dalam memasarkan produk. Oleh karena itu, peneliti perlu menguji hipotesis tersebut. Simulasi merupakan pilihan bagi peneliti untuk menguji konsep dan teori yang dikembangkan serta memahami interaksi antar pemangku kepentingan dalam fenomena ini.

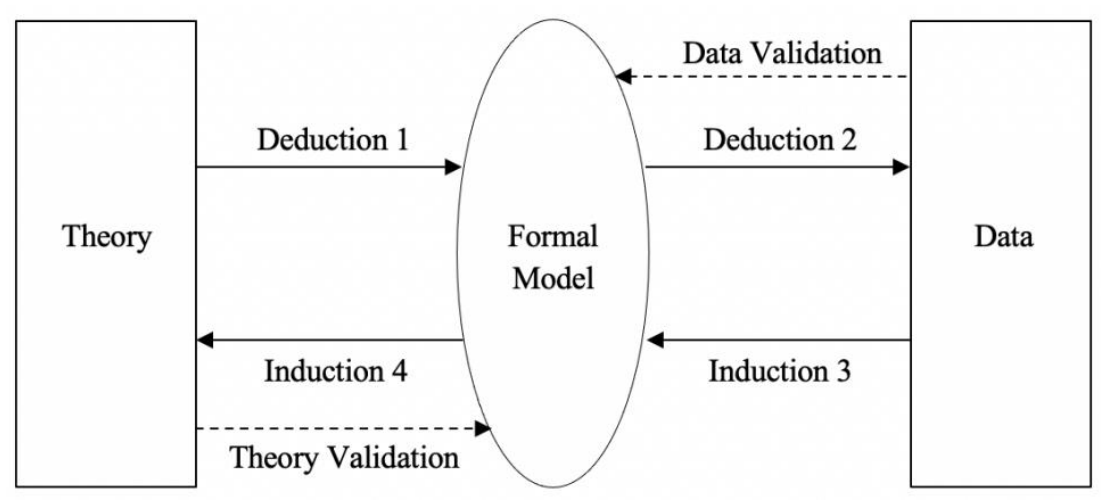

Gambar 2. Proses Penelitian Simulasi

Sumber: Schwaninger dan Grosser (2008)

Penelitian ini menggunakan agent-based modeling (ABM) untuk memahami pengaruh media sosial dan keputusan pembelian produk. Penelitian ini menggunakan metode kombinasi pendekatan deduksi dan induksi (Schwaninger \& Grosser, 2008). Argumen ini bertujuan untuk mendapatkan informasi yang paling relevan untuk dieksekusi dalam model komputasi (Gambar 2). Saat menggunakan deduksi, validasi data perlu dilakukan untuk melakukan model formal yang sesuai dengan data yang tersedia. Sebaliknya pada pendekatan induksi perlu dilakukan validasi teori agar model formal mengikuti teori yang ada. Pendekatan induksi menggunakan observasi dan wawancara mendalam. Instrumen observasi bertujuan untuk memahami proses interaksi dan wawancara mendalam untuk mendapatkan parameter yang berlaku dalam simulasi. Prinsip kombinasi ini berusaha untuk menyesuaikan data yang tersedia dengan teori yang berkembang.

Instagram merupakan studi kasus yang digunakan untuk mendukung penelitian ini. Seperti halnya Instagram, media sosial adalah platform untuk interaksi antara "agen", influencer, dan konsumen. Instagram adalah platform pemasaran media sosial yang berkembang pesat belakangan ini. 
Jurnal Riset Manajemen Sains Indonesia (JRMSI) | Vol 12, No. 2, 2021 e-ISSN: 2301-8313 http://doi.org/10.21009/JRMSI

Meski pengguna aktif Instagram tidak sebanyak Facebook, YouTube, dan Whatsapp, Instagram memiliki kelebihan yang unik. Misalnya, dalam pemasaran media sosial, Instagram memiliki fitur yang tidak dimiliki oleh pesaing langsungnya, Facebook. Sejak awal, Instagram telah menawarkan gambar sebagai proposisi nilai utamanya. Fitur tambahan, seperti tagar dan Instastory, berkontribusi pada daya saing aplikasi dengan pelanggannya.

Simulasi penelitian ini menggunakan aplikasi spot-oriented agent role simulator (SOARS). Tokyo Institute of Technology mengembangkan aplikasi SOARS untuk menjawab keterbatasan dalam menggunakan aplikasi simulasi ilmu sosial yang masih dalam pengembangan (misalnya NetLogo, MASON, Swarm, dan beberapa aplikasi lainnya). SOARS lebih nyaman diterapkan karena tidak memerlukan technical coding. Namun, pengguna harus menguasai logika pemrograman dan pemahaman yang baik tentang interaksi sosial.

\section{Tentukan Parameter}

TPB menjelaskan bahwa keputusan pembelian ditentukan oleh tiga faktor utama: sikap, norma subjektif, dan kontrol perilaku yang dirasakan. Sikap merupakan respon positif terhadap pengetahuan dan pengalaman menggunakan suatu produk. Sikap positif akan berimplikasi pada keputusan pembelian dan sebaliknya. Norma subjektif adalah bentuk tanggapan terhadap orang lain yang dianggap vital di sekitarnya. Jika individu merasa lingkungan sosialnya terpengaruh secara positif, maka akan berimplikasi pada melakukan pembelian. Dalam kontrol perilaku yang dirasakan, penelitian ini mengasumsikan bahwa semua individu dapat memperoleh produk tersebut. Asumsi ini digunakan untuk mengidentifikasi faktor-faktor yang lebih terukur dalam menguji keputusan pembelian.

Tabel 1. Dasar Pemikiran Parameter

\begin{tabular}{|c|c|c|c|c|}
\hline Parameters & Rationale & $\begin{array}{l}\text { Influencer } \\
\quad \text { A }\end{array}$ & $\begin{array}{l}\text { Influencer } \\
\text { B }\end{array}$ & $\begin{array}{l}\text { Influencer } \\
\quad \mathrm{C}\end{array}$ \\
\hline Attraction & The unique appeal of influencers & $1 / 3$ & $1 / 3$ & $1 / 3$ \\
\hline Followers & $\begin{array}{l}\text { Number of active followers who } \\
\text { follow influencer account }\end{array}$ & $\begin{array}{l}\text { More than } \\
100,000\end{array}$ & $\begin{array}{l}80,000- \\
100,000\end{array}$ & $\begin{array}{l}60,000- \\
\text { less than } \\
80,000\end{array}$ \\
\hline $\begin{array}{l}\text { Likes or } \\
\text { Comments }\end{array}$ & $\begin{array}{l}\text { Awards received by influencers as a } \\
\text { response to content created }\end{array}$ & 0.3 & 0.2 & 0.1 \\
\hline $\begin{array}{l}\text { Posting (per } \\
\text { day) }\end{array}$ & $\begin{array}{l}\text { The number of content influencers } \\
\text { creates to attract followers or responses }\end{array}$ & One time & Two times & One time \\
\hline
\end{tabular}


Jurnal Riset Manajemen Sains Indonesia (JRMSI) | Vol 12, No. 2, 2021 e-ISSN: 2301-8313 http://doi.org/10.21009/JRMSI

Parameter khusus penelitian ini adalah ketertarikan, pengikut, suka atau komentar, dan posting (lihat Tabel 1). Daya tarik adalah daya tarik unik seorang influencer, yang membantu menarik pengikut ke akunnya (Miles, 2013). Jumlah pengikut adalah jumlah pengikut aktif yang dimiliki influencer dalam menanggapi akun media sosial (Jin et al., 2019). Selanjutnya, suka atau komentar merupakan penghargaan kepada influencer untuk konten yang dibuat di akun mereka. Terakhir, postingan adalah frekuensi konten kreatif yang dibuat oleh influencer untuk memberikan wawasan tentang pengikut mereka.

Perlu ditentukan parameter tambahan berupa ekspresi rumus untuk merumuskan proses interaksi (Tabel 2). Penjualan produk dipengaruhi oleh harga total dan kuantitas produk. Harga dalam penelitian ini ditetapkan sebesar Rp35.000 per unit barang. Sedangkan jumlah produk yang terjual merupakan keputusan pembelian konsumen karena pengaruh media sosial influencer. Efek influencer adalah akumulasi pengaruh influencer media sosial pada pengikut mereka. Sedangkan keputusan untuk melakukan pembelian merupakan batasan nilai ketika pengikut membeli suatu produk.

Tabel 2. Parameter Proses dan Rumus Ekspresi

\begin{tabular}{ll}
\hline \multicolumn{1}{c}{ Process Parameters } & \multicolumn{1}{c}{ Formula Expression } \\
\hline Product Sales & Price* Quantity \\
Number of Likes/Comments & Likes/Comments * Total Followers \\
Influencer Effect & (Number of Likes or Comments * Posting-Frequency)/Total \\
& Followers \\
Purchasing Decision & Influencer Effect $\geq$ Random * 100 \\
\hline
\end{tabular}

\section{HASIL DAN DISKUSI}

Penelitian menggunakan ABM telah menekankan proses mengembangkan interaksi. Secara umum proses simulasi dibagi menjadi dua, yaitu tahap awal dan tahap proses. Langkah awal meliputi parameter yang ditentukan untuk mendukung tahap proses dan mengembangkan model penelitian awal. Sedangkan tahap proses merupakan perkembangan interaksi antar aktor melalui bahasa logis.

\section{Validitas dan Keandalan}

Pengujian model dalam penelitian simulasi menggunakan tiga pendekatan yaitu uji kesesuaian; uji konsistensi; dan utilitas dan efektivitas (Martis, 2006). Pendekatan pengujian validitas dan reliabilitas menggunakan dua dimensi, yaitu model struktur dan model perilaku. Hasilnya, semua uji kecocokan dapat dilalui oleh model yang dikembangkan. Penelitian ini 
Jurnal Riset Manajemen Sains Indonesia (JRMSI) | Vol 12, No. 2, 2021 e-ISSN: 2301-8313 http://doi.org/10.21009/JRMSI

menggunakan validator eksternal untuk membantu objektivitas dan kesesuaian model yang dikembangkan (Tabel 3).

Tabel 3. Simulasi Uji Validitas dan Reliabilitas

\begin{tabular}{lll}
\hline \multicolumn{1}{c}{ Type of Test } & \multicolumn{1}{c}{ Model Structure } & \multicolumn{1}{c}{ Model Behavior } \\
\hline Test of suitability & Structure verification & Sensitivity \\
Test of consistency & Face validity & Behaviour \\
Test of utility and effectiveness & Appropriateness & Counterintuitive \\
\hline
\end{tabular}

\section{Proses Simulasi}

Studi ini mendefinisikan beberapa poin penting dalam model SOARS, antara lain konsumen sebagai agen, tiga influencer berbeda yang dinyatakan sebagai spot, dan toko produk sebagai tempat pembelian produk. Studi ini mendefinisikan 500 konsumen [agen] yang memiliki akses ke media sosial dan terpapar tiga influencer. Penelitian ini menetapkan periode simulasi selama 180 hari. Selama periode tersebut, penelitian ini ingin melihat bagaimana pengaruh social media influencer terhadap penjualan produk.

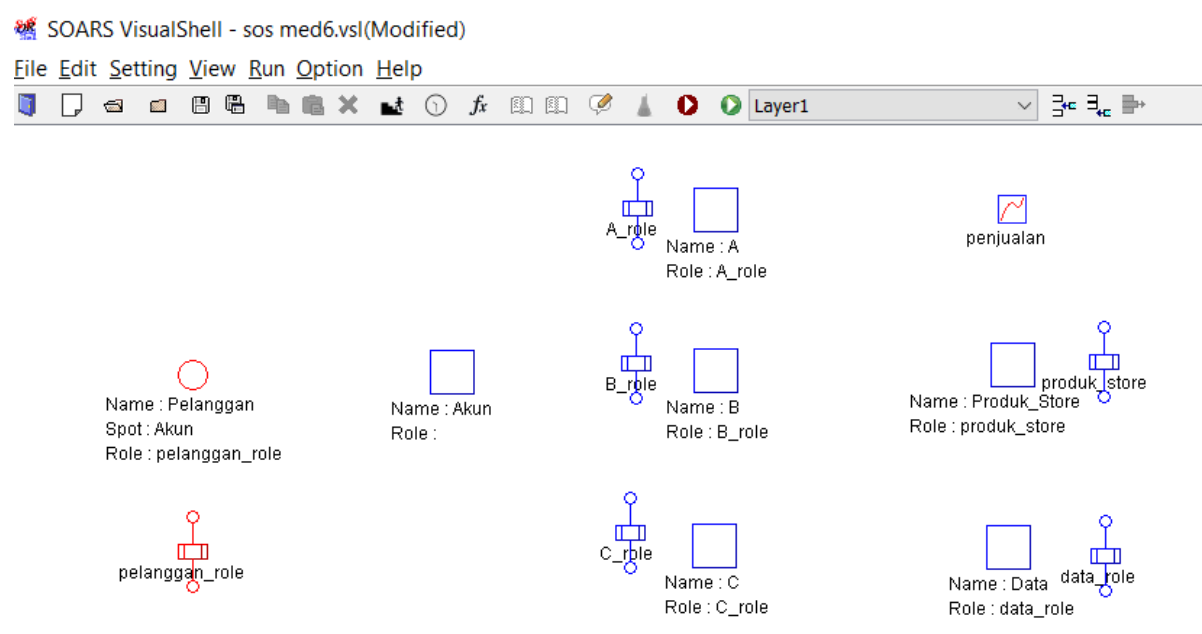

\section{Gambar 3. Model Simulasi Influencer Media Sosial}

Proses interaksi yang terjadi pada platform media sosial melibatkan dua tahap. Pertama, penentuan beberapa parameter yang mempengaruhi interaksi sosial antara konsumen dan influencer media sosial terhadap keputusan pembelian produk kecantikan. Parameter awal yang digunakan antara lain menentukan jumlah pengikut, jumlah suka atau komentar, dan jumlah konten yang diposting di akun influencer. Kedua, proses interaksi sosial. Interaksi sosial melibatkan aktor utama dan membutuhkan logika sekuensial; itu juga memungkinkan untuk kemungkinan pilihan, keputusan membeli, atau tidak. Keputusan pembelian ditentukan oleh bagaimana influencer media sosial menyebarkan informasi produk. 
Jurnal Riset Manajemen Sains Indonesia (JRMSI) | Vol 12, No. 2, 2021 e-ISSN: 2301-8313 http://doi.org/10.21009/JRMSI

\section{Hasil Simulasi dan Pengujian Hipotesis}

Simulasi ini berulang beberapa kali. Iterasi pertama menghasilkan Influencer [B] sebagai influencer media sosial paling berpengaruh untuk meningkatkan penjualannya. Influencer [A] ditandai dengan jumlah pengikut 100.000, jumlah suka (3\% dari jumlah pengikut), dan jumlah posting (satu per hari), serta kemungkinan penjualan dari Influencer [A] dari Rp9.730.000. Kemudian, Influencer [B] ditandai dengan jumlah pengikut 80.000 , jumlah suka (2\% dari jumlah pengikut), dan jumlah posting (dua per hari), serta kemungkinan penjualan dari Influencer [B] ] sebesar Rp13.930.000. Influencer [C] ditandai dengan jumlah pengikut 60.000, jumlah suka (1\% dari jumlah pengikut), dan jumlah posting (satu per hari), serta kemungkinan penjualan dari influencer A Rp3.570.000 . Hasil serupa dilakukan pada iterasi kedua dan ketiga.
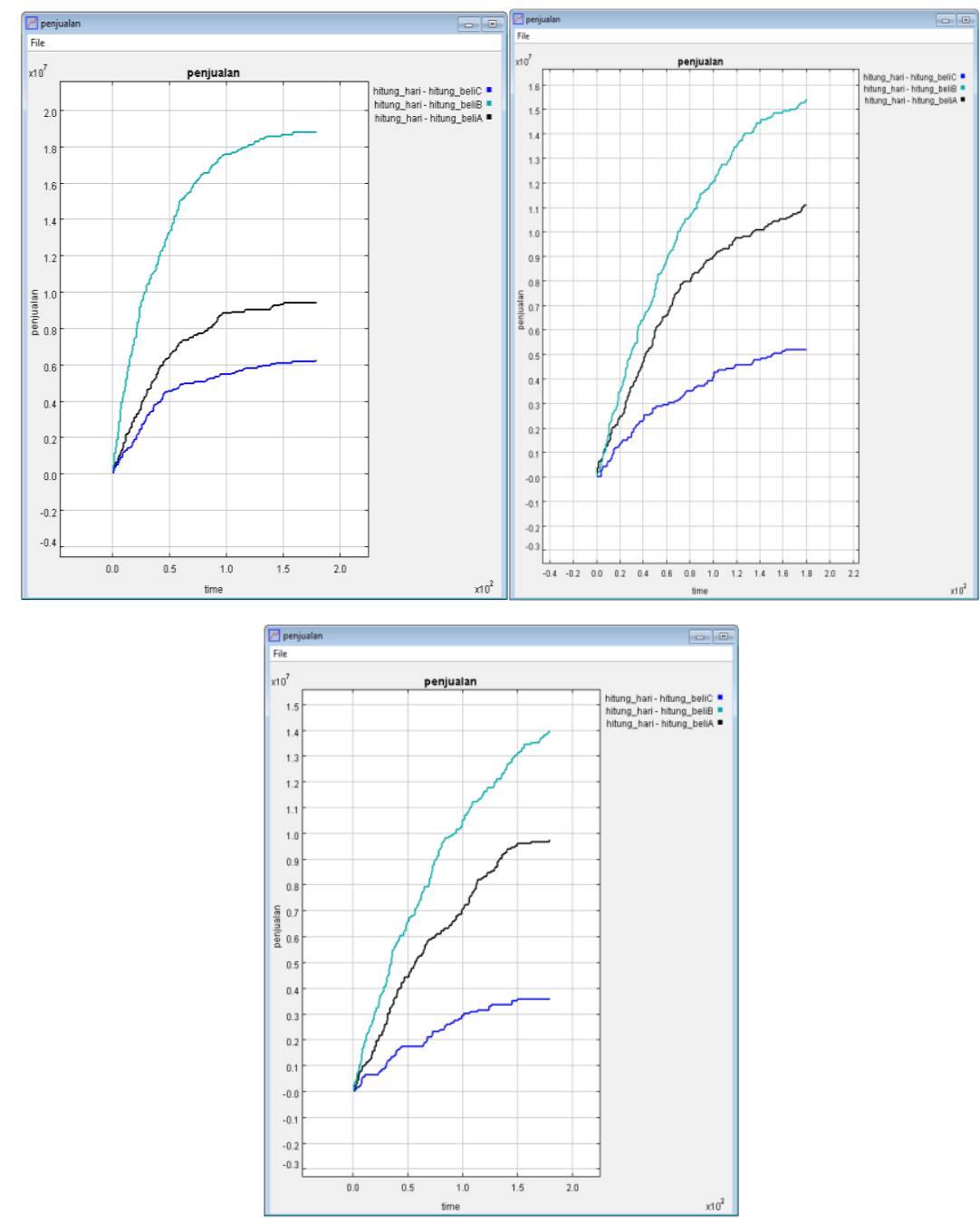

Gambar 5. Hasil Iterasi Simulasi 
Jurnal Riset Manajemen Sains Indonesia (JRMSI) | Vol 12, No. 2, 2021 e-ISSN: 2301-8313 http://doi.org/10.21009/JRMSI

Iterasi kedua dan ketiga juga memunculkan Influencer [B] sebagai influencer media sosial paling berpengaruh. Influencer [A] menghasilkan Rp11.060.000 pada iterasi kedua dan Rp9.730.000 pada iterasi ketiga dengan karakteristik yang sama. Sementara itu, Influencer [B] dapat mengembangkan masing-masing Rp15.400.000 dan Rp13.930.000 pada iterasi kedua dan ketiga. Melalui iterasi serupa, Influencer [C] menghasilkan Rp 5.180.000. Dari beberapa iterasi, dapat disimpulkan bahwa Influencer [B] dengan karakteristik tertentu melalui model komputasi selalu menghasilkan penjualan produk tertinggi. Pada saat yang sama, penjualan produk melalui Influencer [A] dan Influencer [C] mengikuti.

Hasil simulasi menjelaskan bahwa peran social media influencer dalam mempengaruhi keputusan pembelian produk. Semua hipotesis yang dikembangkan diterima (Tabel 4). Melalui influencer media sosial, simulasi melakukan penjualan yang signifikan meskipun perbedaan penjualan ketiga influencer. Oleh karena itu, hipotesis yang dikembangkan pada H1 diterima. Interaksi antara agen, influencer media sosial, dan konsumen memainkan peran penting dalam meningkatkan penjualan produk. Pengertian ini mendukung Hipotesis H2 yang diterima. Terakhir, perbedaan karakter dari ketiga influencer tersebut menghasilkan penjualan yang beragam. Oleh karena itu, organisasi perlu merumuskan karakter dalam pemilihan influencer media sosial. Hasil ini menunjukkan bahwa H3 diterima.

Table 4. Hypothesis Testing

\begin{tabular}{ll}
\hline Hypothesis & Results \\
\hline$H_{1}$ & Accepted \\
$H_{2}$ & Accepted \\
$H_{3}$ & Accepted \\
\hline
\end{tabular}

\section{Diskusi}

Penelitian ini menjelaskan fenomena social media influencer melalui penyusunan mikrostruktur, logika interaksi antar aktor, dan proses interaksi antar aktor selama pembelian produk kecantikan. Aktor kunci dalam fenomena media sosial influencer melibatkan influencer dan konsumen. Social media influencer berperan sebagai aktor yang mempengaruhi konsumen dalam membeli produk. Interaksi ini terjadi pada platform media sosial, yaitu Instagram, yang telah memperluas fungsi yang tidak lagi bersifat pribadi dan mencakup kepentingan komersial. Beberapa perbedaan karakter influencer dimunculkan karena dalam praktiknya setiap individu memiliki karakter yang berbeda-beda. 
Jurnal Riset Manajemen Sains Indonesia (JRMSI) | Vol 12, No. 2, 2021 e-ISSN: 2301-8313 http://doi.org/10.21009/JRMSI

Hasil simulasi dapat menjawab event social media influencer melalui TPB pada pembelian suatu produk kecantikan. Interaksi sosial melalui ilustrasi simulasi mengungkapkan bahwa semua variabel dalam TPB memberikan penekanan yang signifikan terhadap perilaku pembelian konsumen. Influencer media sosial dapat mengontrol faktor sikap individu (Giampietri et al., 2018; Merminod et al., 2019). Sikap pribadi adalah keyakinan seseorang yang dipengaruhi oleh pengetahuan dan pengalaman. Kehadiran influencer dapat memberikan kontribusi yang signifikan terhadap kedua hal tersebut. Influencer mempengaruhi individu melalui penyebaran informasi tentang produk secara visual, tertulis dan gambar. Individu yang merasa cocok dengan daya tarik dan cara influencer menyebarkan informasi mengungkapkan implikasi untuk meningkatkan sikap mereka. Secara paralel, influencer juga dapat mempengaruhi variabel lain, norma subjektif, dan kontrol perilaku yang dirasakan.

Influencer media sosial adalah sosok yang mempengaruhi individu untuk melakukan perilaku pembeliannya (De Veirman et al., 2017; Youn \& Jin, 2017). Sosok ini menjadi panutan karena memiliki daya tarik tertentu dan dapat menyebarkan informasi, yaitu pengaruh relatif influencer. Influencer memiliki keahlian khusus dalam menyebarkan informasi produk. Karakteristik produk dan influencer memiliki hubungan yang erat. Semakin cocok sosok influencer dengan seorang individu, semakin subjektif kepercayaan yang dimiliki individu tersebut. Perilaku influencer akan menjadi acuan bagi individu untuk membeli suatu produk. Dapat disimpulkan bahwa media sosial influencer merupakan instrumen individu yang penting dalam mempengaruhi keputusan pembelian.

Fenomena influencer media sosial mempengaruhi proses perilaku individu (Nuttavuthisit \& Thøgersen, 2017; Pappas, 2017). Perilaku pembelian suatu produk bukanlah proses yang spontan melainkan proses yang kompleks. Ketika individu terpapar informasi menarik dari influencer media sosial, mereka tidak langsung bereaksi untuk melakukan pembelian. Individu akan memproses semua informasi yang diperoleh sebelum memutuskan untuk membeli atau tidak membeli. Kontrol perilaku yang positif akan berusaha untuk mendapatkan produk meskipun banyak tantangan yang akan dihadapi individu. Perilaku kontrol negatif akan menghentikan semua upaya pembelian, meskipun seseorang memiliki keyakinan kuat terhadap produk yang diprakarsai oleh influencer media sosial. Dalam hal ini, social media influencer dapat memberikan stimulus kepada individu untuk mendorong kontrol perilaku ke arah yang positif (Awaluddin \& Hamid, 2019; Piroth et al., 2020). Berbagai tantangan dalam membeli 
Jurnal Riset Manajemen Sains Indonesia (JRMSI) | Vol 12, No. 2, 2021 e-ISSN: 2301-8313 http://doi.org/10.21009/JRMSI

produk dapat dihilangkan dengan mendorong individu untuk membeli produk yang didukung oleh influencer media sosial.

Oleh karena itu, sesuai dengan TPB, semua variabel dalam interaksi antara calon pembeli dan influencer media sosial merupakan faktor signifikan yang mempengaruhi pengambilan keputusan konsumen dalam pembelian produk, misalnya, daya tarik influencer, jumlah pengikut, jumlah suka/komentar, dan jumlah postingan di akun media sosial mereka. Oleh karena itu, beberapa hal yang perlu diperhatikan bagi organisasi untuk membantu meningkatkan penjualan produk melalui pengaruh media sosial: 1). Daya tarik influencer [preferensi konsumen] membutuhkan perhatian penting. Para influencer media sosial harus bisa merepresentasikan produk. Daya tarik influencer mendorong potensi peningkatan kesadaran konsumen terhadap suatu produk. 2). Menggunakan influencer media sosial dengan jumlah pengikut tertentu akan membantu konsumen membeli produk tertentu. Peningkatan jumlah followers bertujuan agar calon konsumen terhadap keputusan pembelian. 3). Jumlah suka/komentar mewakili kualitas seorang influencer pada jumlah pengikut yang dimilikinya. Semakin baik jumlah suka/komentar, semakin tinggi pengaruh influencer effect terhadap konsumen. Oleh karena itu, sebuah organisasi perlu mempertimbangkan influencer media sosial yang berkualitas. 4). Banyak influencer yang memposting di akun media sosial mereka dapat membantu meningkatkan kesadaran konsumen dan pengambilan keputusan pembelian. Influencer yang konsisten dalam memposting jumlah tertentu adalah parameter khusus bagi organisasi untuk menentukan influencer.

\section{KESIMPULAN DAN SARAN}

\section{Kesimpulan}

Penelitian ini ingin menjelaskan bagaimana proses media sosial influencer mempengaruhi perilaku pembelian melalui model komputasi. Oleh karena itu, TPB digunakan sebagai kerangka penelitian untuk memahami interaksi fenomena influencer. Data/informasi dikonstruksi sesuai dengan kerangka penelitian melalui wawancara dan observasi. Meskipun beberapa asumsi dibangun, dan data diperoleh melalui observasi, influencer media sosial masih memiliki pengaruh yang signifikan terhadap penjualan produk, sebagai berikut: 1). Influencer [A] ditandai dengan jumlah pengikut 100, jumlah suka (3\% dari jumlah pengikut), dan jumlah posting (satu per hari), serta kemungkinan penjualan dari Influencer [A] sebesar Rp9 ,380,000. 2). Influencer [B] ditandai dengan jumlah pengikut 80 , jumlah suka ( $2 \%$ dari jumlah pengikut), dan jumlah posting (dua per hari), serta kemungkinan penjualan dari Influencer [B] sebesar 
Jurnal Riset Manajemen Sains Indonesia (JRMSI) | Vol 12, No. 2, 2021 e-ISSN: 2301-8313 http://doi.org/10.21009/JRMSI

Rp18 ,700,000. 3). Influencer [C] ditandai dengan jumlah pengikut 60, jumlah suka (1\% dari jumlah pengikut), dan jumlah posting (dua per hari), serta kemungkinan penjualan dari Influencer [A] sebesar Rp6 ,230.000

Organisasi harus mempertimbangkan beberapa aspek ketika memilih influencer media sosial. Beberapa elemen yang harus diperhatikan antara lain daya tarik pribadi, jumlah pengikut, jumlah suka/komentar, dan postingan. Organisasi dapat menjadi strategis dengan menggunakan keempat parameter ini untuk meningkatkan kesadaran dan penjualan produk mereka.

\section{Saran}

Studi ini mengidentifikasi dua keterbatasan. Pertama, penelitian ini menggunakan beberapa variabel yang mempengaruhi konsumen influencer, misalnya, daya tarik pengikut, jumlah pengikut, jumlah suka/komentar, dan jumlah posting. Studi berikut mungkin menggunakan variabel yang lebih kompleks untuk memberikan gambaran lengkap tentang keputusan pembelian melalui pendekatan kualitatif lain yang relevan (FGD dan wawancara mendalam yang lebih rinci). Kedua, data yang digunakan disajikan secara visual pada akun Instagram influencer. Data ini hanya dapat dijelaskan dari perspektif kuantitatif tetapi belum dijelaskan dari perspektif kualitatif. Oleh karena itu, penelitian-penelitian selanjutnya membutuhkan justifikasi kualitatif untuk memperkuat variabel-variabel yang digunakan.

\section{PENGHARGAAN}

Studi ini ingin mengucapkan terima kasih kepada Dr Manahan Siallagan atas masukan konstruktifnya selama pengembangan model berbasis komputasi. Penulis juga mengapresiasi Andi Sigit Trianto dan Hakiim Noor Rachman atas bantuannya dalam proses pengumpulan dan pembahasan data. 
Jurnal Riset Manajemen Sains Indonesia (JRMSI) | Vol 12, No. 2, 2021 e-ISSN: 2301-8313 http://doi.org/10.21009/JRMSI

\section{DAFTAR PUSTAKA}

Ajzen, I., \& Sheikh, S. (2013). Action versus inaction: Anticipated affect in the theory of planned behavior. Journal of Applied Social Psychology, 43(1), 155-162. https://doi.org/10.1111/j.1559-1816.2012.00989.x

Awaluddin, I., \& Hamid, W. (2019). Interaction of social identity, empathy and planned behavior theories to understand domestic product purchasing intention. Problems and Perspectives in Management, 17(1), 95-102. https://doi.org/10.21511/ppm.17(1).2019.09

De Veirman, M., Cauberghe, V., \& Hudders, L. (2017). Marketing through instagram influencers: The impact of number of followers and product divergence on brand attitude. International Journal of Advertising, 36(5), 798-828. https://doi.org/10.1080/02650487.2017.1348035

Garcia, R., \& Jager, W. (2011). From the Special Issue Editors: Agent-Based Modeling of Innovation Diffusion. Journal of Product Innovation Management, 28(2), 148151. https://doi.org/10.1111/j.1540-5885.2011.00788.x

Giampietri, E., Verneau, F., Del Giudice, T., Carfora, V., \& Finco, A. (2018). A Theory of Planned behaviour perspective for investigating the role of trust in consumer purchasing decision related to short food supply chains. Food Quality and Preference, 64(June), 160-166. https://doi.org/10.1016/j.foodqual.2017.09.012

Gomber, P., Kauffman, R. J., Parker, C., \& Weber, B. W. (2018). On the Fintech Revolution: Interpreting the Forces of Innovation, Disruption, and Transformation in Financial Services. Journal of Management Information Systems, 35(1), 220-265. https://doi.org/10.1080/07421222.2018.1440766

Jin, S. V., Muqaddam, A., \& Ryu, E. (2019). Instafamous and social media influencer marketing. Marketing Intelligence and Planning, 37(5), 567-579. https://doi.org/10.1108/MIP-09-2018-0375

Jinyevu, S. A., Mkonya, V. L., \& Dantur, M. L. (2018). Exploring the Use of Consumer Endorser Strategy in Social Media Product Promotion Advertisement and Its Impacts on Young Consumers Behavior in Tanzania. Proceedings of the 15th International Conference on Innovation \& Management, 764-770.

Macal, C. M., \& North, M. J. (2009). Agent-based modeling and simulation. Proceedings of the 2009 Winter Simulation Conference, 86-98. 
Jurnal Riset Manajemen Sains Indonesia (JRMSI) | Vol 12, No. 2, 2021 e-ISSN: 2301-8313 http://doi.org/10.21009/JRMSI

Martis, M. S. (2006). Validation of simulation based models: A theoretical outlook. Electronic Journal of Business Research Methods, 4(1), 39-46.

Merminod, N., Large, R. O., \& Paché, G. (2019). Procurement of advanced logistics services: proposition of a reasoned action model of individual buying behavior. Supply Chain Forum, 20(3), 169-184. https://doi.org/10.1080/16258312.2018.1555635

Miles, J. G. (2013). Instagram Power: Build Your Brand and Reach More Customers with the Power of Pictures (1st Editio). McGraw-Hill Education.

Miralles, F., Giones, F., \& Gozun, B. (2017). Does direct experience matter? Examining the consequences of current entrepreneurial behavior on entrepreneurial intention. International Entrepreneurship and Management Journal, 13(3), 881-903. https://doi.org/10.1007/s11365-016-0430-7

Nuttavuthisit, K., \& Thøgersen, J. (2017). The Importance of Consumer Trust for the Emergence of a Market for Green Products: The Case of Organic Food. Journal of Business Ethics, 140(2), 323-337. https://doi.org/10.1007/s10551-015-2690-5

Pan, J. Y., \& Truong, D. (2018). Passengers' intentions to use low-cost carriers: An extended theory of planned behavior model. Journal of Air Transport Management, 69(November 2017), 38-48. https://doi.org/10.1016/j.jairtraman.2018.01.006

Pappas, N. (2017). Effect of marketing activities, benefits, risks, confusion due to over-choice, price, quality and consumer trust on online tourism purchasing. Journal of Marketing Communications, 23(2), 195-218. https://doi.org/10.1080/13527266.2015.1061037

Piroth, P., Ritter, M. S., \& Rueger-Muck, E. (2020). Online grocery shopping adoption: do personality traits matter? British Food Journal, 122(3), 957-975. https://doi.org/10.1108/BFJ-08-2019-0631

Schwaninger, M., \& Grosser, S. (2008). System Dynamics as Model-Based Theory Building. Systems Research AndBehavioral Science, 25, 447-465. https://doi.org/10.1002/sres

Tuten, T. L. (2008). Advertising 2.0: Social Media Marketing in a Web 2.0 World. Preager.

Watts, D. J., \& Dodds, P. S. (2014). Influentials, Networks, and Public Opinion Formation. Journal of Consumer Research, 34(4), 441-458.

Yin, R. K. (2014). Case Study Research Design and Methods (5th ed.). Sage.

Youn, S., \& Jin, S. V. (2017). Reconnecting with the past in social media: The moderating role 
Jurnal Riset Manajemen Sains Indonesia (JRMSI) | Vol 12, No. 2, 2021 e-ISSN: 2301-8313 http://doi.org/10.21009/JRMSI

of social influence in nostalgia marketing on Pinterest. Journal of Consumer Behavior, 16(6), 565-576. https://doi.org/10.1002/cb.1655 